\title{
THE ICE RAILWAY*
}

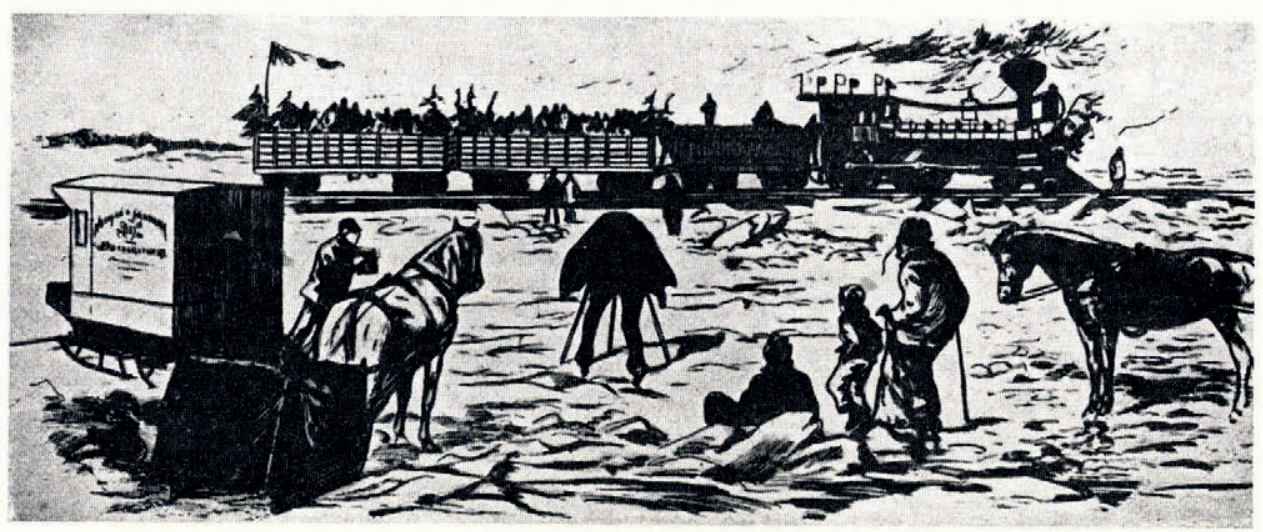

THIs scene is a contemporary artist's impression of a photographer under the usual black cloth taking a picture of the inaugural train on the St. Lawrence River in January I880.

The scheme was formulated in order to connect the Quebec, Montreal, Ottawa and Occidental Railway's line from the north, with that of the South Eastern Railway's route to New England on the other side of the river. The only bridge at that time was that of the Grand Trunk Railway of Canada, some distance further up-stream.

The ice was found to be 2 to 4 feet $(0 \cdot 6-\mathrm{I} \cdot 2 \mathrm{~m}$.). In order to distribute the weight of the train over a wide area of ice, large timbers varying in length from 12 to 14 feet $(3 \cdot 6-7 \cdot 3 \mathrm{~m}$.) were laid crossways, with similar timbers lengthwise above these. On top of these ordinary sleepers were laid.

The official opening took place on $3^{1}$ January 1880 , when a special train, consisting of the small locomotive "W. H. Pangman" and two flat cars fitted with railings and seats, set out with a load of government, civic and railway officials and guests; while other, less venturesome guests, crossed the river in sleighs on the nearby and parallel road.

The total weight of the train with its $25^{\circ}$ passengers aboard was estimated at 60 tons. The train stopped to be photographed but, when it started again, the passengers were amused to see the photographer running after it, waving his arms wildly and shouting "Arrêtez! Arrêtez! J'ai manqué mon coup!"

The crossing was successfully accomplished, at an average speed of ten miles per hour, and on arrival at the south shore, the guests were treated to a banquet in the Longueuil station of the South Eastern Railway. The line was used for about two months, although after the middle of March the use of the locomotive was discontinued and horses substituted. The track was taken up at the end of the month, and on 17 April, the river being now clear of ice, the new car ferry "South Eastern" began running.

The scheme worked with varying fortune each winter for four years. After that the Canadian Pacific Railway took over, and in 1887 the Saint Lawrence Bridge, near Lachine, was completed.

* Acknowledgement is made to the Canadian Railway Historical Association of Montreal, and to a pamphlet in the Society's Library, The Ice Railway, by Robert P. Brown. 